\title{
Agenda Lanjutan Pasca Institusionalisasi Zakat ${ }^{1}$
}

\author{
Arif Hartono
}

\begin{abstract}
The obligation of zakat has special characteristic in Islam. Except as a way to obey and to play. the religion rule, zakat also has the economical implication. Except as an individual compulsory, zakat also has the social implication. By legalized Ordinance number 38/1999 about management of zakat, it is hoped that the advantage of zakat can be more optimal. But, that ordinance should be followed by the others agenda, politically or economically, as the implication of the use of that ordinance.
\end{abstract}

\section{Pendahuluan}

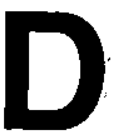

isahkannya Undang-Undang nomor 38 tahun 1999 tentang Pengelolaan Zakat adalah fenomena menarik sebagai bagian dari dinamika dialektika politik, ekonomi dan keagamaan (Islam) dalam kehidupan bernegara. Betapa tidak, zakat yang selama ini lebih banyak dianggap sebagai kewajiban individual-religius yang dalam pengelolaannya lebih banyak diserahkan kepada umatnya secara otonom kemudian bergeser menjadi sebuah pranata formal-legalistik yang diatur oleh negara.

Dalam perspektif ekonomi, institusionalisasi zakat ini dapat dianggap sebagai pengakuan formal negara atas zakat sebagai salah satu resources pembangunan. Pengakuan ini tentu saja membawa implikasi lebih lanjut berupa keterlibatan negara dalam pengelolaan zakat ini dan sekaligus memikirkan lebih lanjut tentang keber: adaannya sebagai bagian dari variabel model ekonomi secara keseluruhan. Artinya, institusionalisasi zakat ini menuntut adanya adjusment lebih lanjut dari negara, baik dalam artian konsepsi, modellingnya dalam sistem bahkan sampai pada operasionalisasinya. Ketika hal ini dilakukan, maka pada saat yang sama sebenarnya perbincangan mengenai zakat telah memasuki wilayah dialektika politik. Tawarmenawar dan akomodasi berbagai kepentingan akan menjadi bagian tak terpisahkan dari pergulatan lebih lanjut mengenai zakat ini.

'Gagasan penulis tentang pengoptimalan zakat sebagai instrumen pembangunan ekonomi sudah pernah dimuat dalam Jurnal Ekonomi (Januari-1996). Tulisan ini merupakan telaah lebih lanjut untuk mencoba mengaitkan gagasan penulis dengan fenomena kelahiran Undang-Undang No 38 Tahun 1999 tentang Pengelolaan Zakat serta Keputusan Menteri Agama No 581 tentang Pelaksanaan UU Pengelolaan Zakat. 
Topik: Agenda Lanjutan Pasca lnstitusionalisasi Zakat, Arif Ilartono

Tulisan ini mencoba untuk menganalisis urgensi zakat dalam sebuah sistem, implikasi dari institusionalisasi pengelolaan zakat serta agenda-agenda apa yang seharusnya dilakukan agar maksud dari UU No 38 tahun 1999 dapat tercapai secara optimal. Karena keterbatasan penulis, maka analisis lebih banyak dalam perspektif ekonomi sementara untuk perspektif politik penulis hanya memberikan sinyalsinyal arah agenda yang harus segera ditindaklanjuti.

\section{Konsepsi Zakat: Review Singkat}

Islam, adalah agama samawi yang berdimensi lengkap mencakup ajaran yang sangat universal berupa jasmani-rohani, dunia-akhirat, individu maupun sosial. Salah satu ajaran dalam Islam yang 'istimewa' adalah zakat, dikarenakan karakteristik khas yang dimilikinya. Selain berdimensikan vertikal-transendental, ia juga mempunyai nilai humanis-horisontal. Di samping itu zakat juga bernilaikan individu sekaligus sosial.

Ditinjau dari segi bahasa, zakat merupakan kata dasar (masdar) dari zaka yang berarti tumbuh, berkah, dan terpuji. Sesuatu itu zaka berarti tumbuh dan berkembang, dan seorang itu zaka berarti orang itu baik. Menurut Lisan al-Arab arti dasar dari kata zakat, ditinjau dari sudut bahasa adalah suci, tunbuh, berkah dan terpuji; semuanya digunakan dalam Al-Qur'an dan Hadits. Dari segi istilah fikih berarti: "Sejumlah harta tertentu yang diwajibkan Allah diserahkan kepada orang-orang yang berhak" di samping berarti "mengeluarkan jumlah tertentu itu sendiri". Jumlah yang dikeluarkan dari kekayaan itu disebut zakat karena yang dikeluarkan itu 'menambah banyak, membuat lebih berarti, dan melindungi kekayaan dari kebinasaan". (Qardawi, 1991: 34-36)
Arti "tumbuh" dan "suci" pada pengertian di atas tidak hanya untuk kekayaan, tetapi lebih dari, juga buat jiwa orang yang menzakatkannya. Bahkan, zakat juga menciptakan pertumbuhan buat orang-orang miskin. Dengan demikian zakat merupakan cambuk ampuh yang tidak hanya untuk menciptakan pertumbuhan material dan spiritual bagi orang-orang miskin, tetapi juga mengembangkan jiwa dan kekayaan orang-orang kaya.

Al-Qur'an dan Sunnah selalu menggandengkan shalat dengan zakat. Ini menunjukkan betapa erat hubungan antara keduanya. Keislaman seseorang tidak akan sempurna kecuali dengan kedua hal tersebut. Shalat merupakan tiang agama; siapa yang menegakkannya berarti menegakkan agama dan siapa yang meruntuhkannya berarti meruntuhkan agama. Sementara itu, zakat merupakan jembatan menuju Islam; siapa yang melewatinya akan selamat sampai tujuan dan siapa yang memilih jalan lain akan tersesat.

Keeratan hubungan dan tingginya nilai ibadah keduanya, tampak pada ucapan Adullah bin Mas'ud, "Anda sekalian diperintahkan menegakkan sholat dan membayar zakat. Siapa yang tidak mengeluarkan zakat maka shalatnya tidak akan diterima". Demikian juga halnya dengan perkataan Jabir dari Zaid, "Shalàt dan zakat adalah kewajiban dalam satu paket, keduanya tidak terpisahkan". (Qardawi, 1995:92) Begitu tingginya nilai zakat dalam Islam, maka tidak mengherankan bila orang yang mengingkari kewajiban zakat akan mendapat sanksi yang sangat keras. Di antara sanksi tersebut adalah tidak dapat dianggap sebagai orang yang beriman (QS. Al-Mukminun:1-4 dan QS. An-Naml:2-3), bahkan mereka tergolong orang yang musyrik (QS. Fushshilat:6-7) dan juga di akhirat dia akan mendapat siksa yang amat pedih (QS. At Taubah: 34) 
Dalam dimensi duniawi Rasulullah juga ' memberi peringatan bila kewajiban zakat tidak dipenuhi maka akan terjadi bencana kekeringan dan kelaparan. Di sámping itu bercampurnya zakat yang tidak dikeluarkan dengan harta lainnya akan merusak harta tersebut.

Mengingat arti pentingnya zakat, baik dalam dimensi ibadàh maupún sosial, maka Islam mengijinkan penguasa menyita separuh dari harta órang yang enggan mengeluarkan zakat. Dan yang lebih keras lagi para ulama menegaskan bahwá siapa yang menolak dan mengingkari wajibnya zakat dianggap kafir dan'keluar dari agama Islam. (Qardawi, 1995:99)

\section{Posisi Zakat dalam. Model Makro Ekonomi}

Secara konvensional, perekonomian secara makro dipilah-pilah menjadi beberapa sektor. Berdasarkan pendekatan pengeluaran (expenditure approach) perekonomian suatu negara secara makro dapat dipilah ke dalam tiga sektor, yaitu: (1) sektor orang perorangan atau rumah tangga; (2) sektor badan usaha atau bisnis; dan (3)sektor, pemerintah. Pembagian sektor ini berlaku bagi perekonomian tertutup, yaitu perekonomian yang hanya meliputi sektor ekonomi dalam negeri, dengan asumsi suatu negára dianggap tidak mempunyai hubungan eko nomi dengan negara lain. Sementara untuk model makro perekonomian terbuka, yaitu perekonomian yang dipengaruhi interaksi dengan negara lain, terdapat satu sektor lagi yaitu sektor perdagangan luar negert (ekspor-impor).

Secara matematis model makro perekonomian tertutup (perekonomian dalam negeri) dapat diformulasikan sebagai berikut:

$$
\mathbf{Y}=\mathbf{C}+\mathbf{I}+\mathbf{G}
$$

$$
\begin{aligned}
& Y=\text { Pendapatan nasional } \\
& \mathbf{C}=\text { Konsumsi sektor perorangan } \\
& \mathbf{I}=\text { Investasi sektor bisnis } \\
& \mathbf{G}=\text { Konsumsi sektor pemerintah }
\end{aligned}
$$

Masing-masing komponen pembentuk pendapatan nasional (tiga sektor) bila ditelusuri proses pembentukannya adalah sebagai berikut:

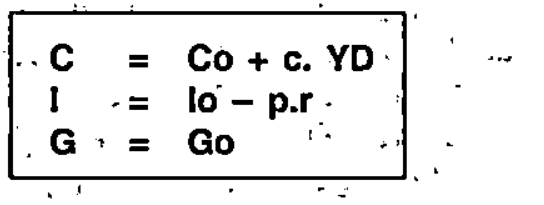

Co, lo, Go adalah konstanta yang mencerminkan pengeluarán-pengeluaran yang sifatnya tetap atau otonom; besarnya tidak tergantung pada atau tidak dipengaruhi oleh sesuatu variabel.

Selain Co, lo dan Go; c dan p juga merupakan konstanta. Konstanta $c$ mencerminkan marginal propensity to consume (MPC), yaitu tambahan pengeluaran untuk konsumsi berkenaan dengan adanya tambahan pendapatan: Sedangkan konstanta p melambangkan proporsi investasi terhadap tingkat suku bunga. Adapun variabel $r$ melambangkan tingkat suku bunga.

YD merupakan pendapatan yang bisa/ siap dibelanjakan (disposable income) oleh sektor perorangan secara makro atau nasional; yaitu pendapatan nasional $(Y)$ dikurangi pajak-pajak (taxes, TX) yang dibayarkan kepada pemerintah ditambah pembayaran transfer (transfer payment, TP) yang diterima oleh sektor ini dari sektor pemerintah. Sehingga YD $=Y-T X+T P$.

2Pembahasan mengenai zakat dalam model makro ekonomi ini mengadopsi gagasan Dumairy (1994) dengan tambahan analisis lebih lanjut oleh penulis dari berbagai sumber. 
Dengan penjelasan variabel-variabel pembentuk komponen pembentuk formula pendapatan nasional tersebut, maka secara lebih terperinci pendapatan nasional dapat dirumuskan sebagai berikut:

$$
\begin{aligned}
& Y=C+1+G \\
& Y=C o+c . Y D+10-p \cdot r+G o \\
& Y=C o+c(Y-T X+T P)+10-p . r+G o
\end{aligned}
$$

Mengingat alokasi pendapatan disposabel (YD) kalau tidak dikonsumsi (C) adalah di tabung (S), maka berdasarkan alokasinya $Y D=C+S$. Sehingga persamaan tabungan perseorangannya adalah:

$$
\begin{aligned}
& S=Y D-C \\
& S=-C o+(1-C) . Y D
\end{aligned}
$$

Dalam pendekatan pengeluaran, variabel tabungan (S) tidak diperhitungkan dalam penghitungan pendapatan nasional (Y) karena bukan merupakan pengeluaran. TX merupakan pengeluaran bagi sektor perorangan tapi pemasukan bagi pemerintah. Sebaliknya, TP merupakan pengeluaran bagi pemerintah tapi pemasukan bagi perorangan. Keduanya bukanlah pengeluaran sejati (mengingat secara makro merupakan pemasukan bagi sektor lain), oleh karenanya keduanya tidak diperhitungkan langsung dalam perhitungan pendapatan nasional; tetapi diperhitungkan melalui pendapatan disposabel (YO).

Masing-masing komponen pembentuk

\begin{tabular}{|c|c|c|c|}
\hline \multicolumn{4}{|c|}{ Neraca Sektor Perorangan } \\
\hline $\begin{array}{l}\text { Assets: } \\
\text { National Income } \\
\text { Transfer Payments }\end{array}$ & $\begin{array}{l}\mathrm{NI} \\
\mathrm{TP}\end{array}$ & $\begin{array}{l}\text { Liabilities: } \\
\text { Taxes Expenses } \\
\text { Consumption } \\
\text { Sávings }\end{array}$ & $\begin{array}{l}\text { TX } \\
\mathrm{C} \\
\mathrm{S}\end{array}$ \\
\hline \multicolumn{4}{|c|}{ Neraca Sektor Bisnis } \\
\hline $\begin{array}{l}\text { Assets: } \\
\text { Saving (from persons) }\end{array}$ & $S$ & $\begin{array}{l}\text { Liabilities: } \\
\text { Invesments }\end{array}$ & 1 \\
\hline \multicolumn{4}{|c|}{ Neraca Sektor Pemerintah } \\
\hline $\begin{array}{l}\text { Assets: } \\
\text { Taxes (from persons) }\end{array}$ & $\mathrm{TX}$ & $\begin{array}{l}\text { Liabilities: } \\
\text { Government Consumption } \\
\text { Transfer Payments }\end{array}$ & $\begin{array}{l}\text { G } \\
\text { TP }\end{array}$ \\
\hline
\end{tabular}
pendapatan nasional secara lebih sederhana bisa ditelusuri dengan mencermati neraca (balance sheet) dari masing-masing sektor adalah sebagai berikut: 
Model makro ekonomi yang konvensional ini dapat dikatakan tidak realistik. Sisi. kredit (liabilities) pada neraca sektor perorangan memperlihatkan bahwa pengeluaran seseorang hanya' terdiri atas pembayaran pajak dan pembiayaan untuk konsum si. Tidak terlihat, baik pada neraca maupun dalam persamaan konvensional, pengeluaran seseorang untuk kepentingan sosial. Begitu pula halnya pada neraca sektor bisnis, tidak terlihat adanya pengeluaran yang menunjukkan tanggung jawab sosial (sosial responsibility) perusahaan-perusahaan. Secara keseluruhan model tadi tidak menunjukkan adanya jalinan hubungan sosial antar ketiga sektor; masing-masing sektor berperilaku ekonomi sebatas fungsi dan kedudukannya sendiri saja.

Melihat kondisi di atas, perlu kiranya ditinjau kembali strukturisasi perekonomian konvensional. Pemilahan sektoral ke dalam tiga sektor yang selama' ini dipakai perlu dilakukan perubahan, karena tidak mampu mengakomodasikan aktivitas sosial sehingga masing-masing sektor dalam perekonomian berperilaku "materialis-individualis".

Hak kepemilikan pribadi átas harta benda disahkan dan diakui eksistensinya dàlam Islam tanpa sedikit pun keraguan di dalamnya. Naluri pemilikan dan kecenderungan untuk memiliki sedemikian kuatnya dalam diri manusia, seolah-olah naluri tersebut menyatu dengan naluri mempertahankan hidup. Dan, Islam tidak menutup mata dengan kenyataan-kenyataan yang ada pada diri manusia tentang kecintaannya terhadap harta sebagaimana dalam ayat 14 surah Ali 'Imran, dan juga tidak memungkiri bahwa harta benda merupakan perlambang dari kehidupan (QS. Al-Kahfi: 47). Eksistensi kepemilikan pribadi juga akan kita jumpai antara lain dalam surah An-Nisaa' ayat 2 dan 43, ataupun dalam surah Al-Kahfi ayat 82.
Tetapi yang harus dipérhatikan bahwa Islam tidaklah membiarkan permilikan pribadi secara mutlak, bebas tanpa kendali dan batas apa pun. Di samping mengakui eksistensi kepemilikan pribadi,' Islam juga menetapkan prinsip-prinsip yang lain, yaitu:

1. Bahwa sesungguhnya individu pada hakekatnya'hanyalah wakil masyarakát yang diserahi memegang dan mengurus - harta benda yang ada dalam tangannya; dan pemilikannya atas harta itu hanya bersifat sebagai 'uang belanja' di mana ia memiliki hak pemilikan yang lebih besär dari orang lain. Sedangkan sesungguhnya harta' bënida secara umum adalah hak milik masyarakat, dan masyarakat adalah wakil yang diserahi Allah untuk mengurus harta tersebut. Pemilik yang sebenarnya dari segala sesuatu adalah Allah.

2. Imam atau kepala negara - sebagai manifestasi dari wakil masyarakat ahli waris bagi orang-orang yang tidak mempunyai ahli waris. Karena harta mereka sesungguhnya milik masyarakat yang diserahkan kepada mereka untuk mengurusnya. Maka bila tidak ada ahli waris, kembalilah harta tersebut - kepada asalnya, yakni masyarakat.

3. Harta benida tidak boleh hanya berada di tangan sekelompok anggota masyarakat tertentu saja, dan hanya beredar di lingkungan mereka sajá, sementara kelompok masyarakat yang lain tidak menikmatinya. (lihat QS. Al-Hasyr:7-9)

4. Ada jenis:jenis harta yang menjadi milik masyarakat umum, dan tak boleh dimiliki oleh individu, yaitu harta yang menyangkut hajat hidup orang banyak. Rasulullah menyebutkan tiga di antaranya, yakni air, tumbuh-tumbuhan, makanan ternak dan api. Tentu saja dengan menggunakan Qiyas perluasan. penerapan kategori berdasarkan hikmah 
yang terkandung di dalamnya dapat dilakukan. (Qutb, 1984:140-152)

Dengan deskripsi di atas jelaslah bahwa harta benda tidak boleh dibenci dan hasrat untuk memilikinya tidak boleh dimatikan atau dibekukan, tetapi hanyalah dijinakkan dengan ajaran qanaah (rasa penghargaan untuk mensyukuri apa yang sudah dimiliki yang mengarah kepada suatu kepuasan); dan dengan ajaran cinta kepada sesama dalam rangka ajaran kemasyarakatan. Kemudian hasrat tersebut dikendalikan dengan ajaran zakat, infaq dan shadaqah (pengeluaran atau pemanfaatannya kepada kemaslahatan diri dan masyarakat, dan juga realisasi transendentalitas kepada Khaliq), juga dalam rangka ajaran kemasyarakatan. (lihat Yafie, 1994:167-169)
Islam mengajarkan, manusia bukanlah sekadar makhluk individu, tetapi juga makhluk sosial. Dalam konteks ekonomi, kedudukan manusia sebagai makhluk sosial ini dalam Islam dimanifestasikan antara lain berupa kewajiban zakat, serta sunnah berinfak dan bersedekah; disamping itu sebagai warga negara seorang muslim juga wajib membayar zakat. Hal ini berarti bahwa pengeluaran tidak hanya berupa biaya konsumsi dan pembayaran pajak, tetapi ada juga pengeluaran sosial antara lain zakat, infak, dan sedekah. Dengan demikian, formulasi model makro ekonomi konvensional perlu dilakukan adjusment menjadi model makro ekonomi Islami sebagai berikut:

\begin{tabular}{|ll|ll|}
\hline \multicolumn{4}{|c|}{ Neraca Sektor Perorangan } \\
\hline Assiets: & & Liabilities: & \\
National Income & NI & Personal Taxes & PTX \\
Transfer Payments & TP & Personal Social Responsibility & PSR \\
& & Personal Consumption & PC \\
& & Personal Savings & PS \\
\hline
\end{tabular}

Tanggung jawab sosial sesungguhnya bukan hanya kewajiban perorangan, tetapi juga perusahaan-perusahaan sehingga harus pula terlihat jelas pada neracanya. Dengan demikian, maka pengeluaran perusahaan bukan semata-mata untuk investasi saja, namun juga pajak dan pengeluaran dalam rangka tanggung jawab sosial. Bahkan, dalam kenyataan sehari-hari perusahaan juga melakukan pengeluaran biaya operasi (bukan investasi). Sehingga neraca yang lebih realistik untuk sektor bisnis adalah sebagai berikut: 


\begin{tabular}{|c|c|c|c|}
\hline \multicolumn{4}{|c|}{ Neraca Sektor Bisnis' } \\
\hline $\begin{array}{l}\text { Assets: } \\
\text { Personal Saving }\end{array}$ & PS & $\begin{array}{l}\text { Liabilities: } \\
\text { Business Taxes } \\
\text { Business Operating Expenses } \\
\text { Business Invesment } \\
\text { Business Social Responsibility }\end{array}$ & $\begin{array}{l}\text { BTX } \\
\text { BOE } \\
\text { BI } \\
\text { BSR }\end{array}$ \\
\hline
\end{tabular}

Untuk pengeluaran pemerintah,dalam model konvensional, pengeluaran peme- . rintah hanya terdiri atas pengeluaran untuk konsumi dan pembayaran transfer, sementara pajak yang diterima berasal dari perorangan. Padahal, pengeluaran konsumsi pemerintah hanyalah pengeluaran rutin, di samping pembiayaan pembangunan (development expenses). Penerimaannya juga bukan hanya bersumber dari perorangan, tetapi juga dari perusahaan-perusahaan. Neraca yang lebih realistik untuk sektor pemerintah adalah:

\section{Neraca Sektor Pemerintah}

Assets:

Personal Taxes

Business Taxes

\section{PTX} BTX
Liabilities:

Government Routine Expenses GRE Develópment Expenses $\mathrm{DE}$ Transfer Payments
Dalam model makro ekonomi. Islami dengan pendekatan pengeluaran, perekonomian domestik tidak hanya terdiri, atas ketiga sektor yang sudah disebutkan. Akan tetapi.terdapat satu sektor lagi, yaitu sektor sosial. Sektor ini mencakup lembaga-lembaga sosial yang ada di masyarakat antara lain yayasan-yayasan, amil zakat, pantipanti asuhan, lembaga swadaya masyara- kat, dan sebagainya. Pendapatan lembagalembaga ini bersumber dari perorangan (berupa personal social responsibility) dan dari perusahaan-perusahaan (berupa business social responsibility). Pendapatan ini mereka keluarkan untuk kesejahteraan sosial masyarakat. Kontribusi lembaga-lembaga sosial bagi kesejahteraan masyarakat seharușnya dimasukkan pula dalam 'perhitungan pendapatan nasional.

\begin{tabular}{|ll|lll|}
\hline & \multicolumn{3}{|l|}{ Neraca Sektor Sosịal } & \\
\hline Așsets: & & Liabilities: & \\
Personal Sosial Responsibility & PSR & Social Routine Expenses & SRE \\
Business Social Responsibility & BȘR & Social.Invesment & SI \\
\hline
\end{tabular}


Dengan masuknya sektor sosial, maka struktur model makro Islami untuk perekonomian domestik (perekonomian tertutup), dengan pendekatan pengeluaran, tidak lagi terdiri atas tiga sektor tetapi empat sektor, yaitu: (1)sektor perorangan/personal sector, (2)sektor bisnis/business sector, (3)sektor sosial/social sector, dan (4)sektor pemerintah/government sector.

Kehadiran sektor sosial dalam model makro ini menyiratkan makna semua pelaku ekonomi dalam perekonomian memiliki kebersamaan dan terjalin dalam ikatan sosial. Jadi, tidak hanya pemerintah saja (melalui TP/transfer payments) yang memikul tanggung jawab sosial; tetapi juga orang-perorangan dan kalangan dunia usaha sebesar PSR (personal sosial responsibility) dan BSR (business social responsibility). Lembaga-lembaga non-profit inilah yang melayani kesejahteraan sosial bagi masyarakat yang karena sebab-sebab struktural tidak memiliki keunggulan personal, tidak terlibat dalam jaringan bisnis, dan bahkan tidak terjangkau oleh layanan sosial pemerintah.

Kehadiran sektor sosial dalam model makro ekonomi memungkinkan kita melakukan telaah tentang apakah pembangunan ekonomi sungguh-sungguh mampu mengentaskan kaum dhuafa dari lembah kemiskinan, dan apakah kemajuan ekonomi juga meningkatkan kesejahteraan sosial secara lebih merata. Distribusi hasilhasil pembangunan beralasan dinyatakan semakin merata (kesenjangan sosial berkurang) hanya jika rasio pengeluaran sosial terhadap pendapatan nasional (rasio social expenditure/SE: national incoem/ $\mathrm{NI}$ ) semakin membesar seiring dengan pertumbuhan ekonomi. Apabila pertumbuhan ekonomi (kenaikan NI) tidak diikuti oleh kenaikan rasio SE/NI secara proporsional, maka itu berarti pembangunan ekonomi justeru memperburuk kesenjangan sosial.
Di samping itu, dapat pula dihitung rasio pengeluaran tiap-tiap sektor personal expenditure, business expenditure, soial expenditure dan government expenditure terhadap national income; sehingga dapat dideteksi apakah suatu perekonomian cenderung kian konsumtif, kapitalistik, sosialistik, ataukah etatis.

Selanjutnya, karena dalam pengeluaran sosial perorangan (personal social responsibility/PSR) terrmasuk pula dana zakat, maka perbandingan besarnya dana zakat nasional terhadap PSR, dapat dijadikan alat untuk mendeteksi tingkat kesadaran umat dalam menunaikan rukun tersebut. Dengan pertumbuhan ekonomi yang pesat, berarti pendapatan nasional meningkat, seharusnya porsi zakat dalam PSR juga meningkat jika kesadaran menunaikan zakat bertambah baik.

Menurut Islam, kekayaan adalah nikmat dan anugerah Allah'yang harus disyukuri. Sebaliknya, ia melihat kemiskinan sebagai masalah, bahkan musibah yang harus dilenyapkan. Islam tidak menerima adanya paham bahwa kemiskinan adalah takdir yang tak bisa dirubah, atau paham yang hanya berisi anjuran/nasihat untuk membantu kemiskinan tanpa aktivitas nyata dan suatu kepastian hukum, dan tidak juga hanya mengandalkan kemurahan hati, demikian juga dengan paham kepemilikan mutlak terhadap harta sehingga sedekah atau tidak adalah terserah dirinya, namun juga tidak bisa menerima paham persamaan yang tidak mengakui eksistensi orang kaya sehingga usaha yang dilakukan adalah menghancurkan orang kaya untuk menuju persamaan.

Kemiskinan adalah penyakit sosial yang harus diatasi karena akan dapat menimbulkan dampak yang sangat komplek dan berkepanjangan. Kemiskinan akan sangat membahayakan akidah — karena kefakiran mendekatkan kekufuran-, akhlak 
dan moral, keluarga, dan juga "mengancam kestabilan pikiran dan masyarakat. Cara penanggulangannya adalah dengan suatu aktivitas yang nyata melalui perintah yang formal. Aktivitas tersebut adalàn zakat ditambah infak dan shodaqoh.

Zakat merupakan aktivitas sosio-religius yang diwajibkan bagi orang dengan kondisi tertentu atas barang tertentu dán ditujukan 'kepada golongan tertentu. Golongan yang menjadi sasaran zakat sèbagaimana Surat At-taubah 60 adalah delapari golongan, yaitu miskin, fakir, amil; muallaf, budak, ghorimin, ibnu sabil dan sabilillah. Walaupun demikian menurut kesepakatan ulama,-yang manjadi penerima utama zakat adalah fakir-miskin. Hal ini menunjukkan betapa tinggi perhatian Islam terhadap kaum miskin melalưi aktivitas yang riil.

Dalam khasanah pemikiran ekonomi, zakat merupakan transfer kekayaan dari si kaya kepada golongan miskin. Dan yang lebih penting lagi bahwa proses ini sangat terjamin kelangsungannya, karena disertai pranata hukum yang penuh kepastian, tidak sebagaimana yang diskenariokan trickle down effect theory.

Dan bila khasanah pemikiran ekonomi ini kita pakai lagi, maka yang akan berkembang adalah bagaimana mencapai manfaat yang sebesar-besarnya dari perbuatan berzakat? Pertanyaan ini layak dimunculkan guna memperoleh nilai guna yang optimal dari aktivitas zakat, sehingga aktivitas yang dilakukan tidak hanya sia-sia. Dalam artian proses transfer terjadi tetapi tidak membawa efek peningkatan kesejahteraan si miskin.

Berpikir zakat secara ekonomi berarti memikirkan zakat sebagai salah satu sumber ekonomi, yang penggunaannya atau pengolahannya harus dilakukan sedemikian rupa sehingga menghasilkan manfaat konsumtif atau produktif yang optimal. Di sini kita dihadapkan pada persoalan memilih berbagai alternatif tindakan atau kebijaksanaan yang kongkretisasinya dapat diwujudkan dalam suatu organisasi atau sistem ekonomi pada berbagai skala dan ruang lingkup.

Walaupun zakat merupakan aktivitas yang bernuansakan sosial-ekonomi, yang harus tetap diingat bahwa seorang muslim yang membayar zakat, berbuat demikian karena Allah. la tak sekedar hanya memberikan kekayaan kepada fakir-miskin, tetapi aktivitas tersebut didasari karena perintah Allah. Zakat merupakan kewajiban yang didasarkan atas kesadaran religius.

Secara filosofis-sosial, zakat dikaitkan dengan prinsip "keadilan sosial" dan dilihat dari segi kebijaksanaan dan strategi pembangunan yang berhubungan dengan masalah distribusi pendapatan masyarakat, pemerataan kegiatan pembangunan, átau pemberantasan kemiskinan. Dengán zakat, di satu sisi terjadi proses transfer konsumsi dan kepemilikan sumber-sumber ekonomi, sementara di sisi lain merupakàn pérluasan kegiatan produktil di tingkat bawah. Skenario ini memberikan kesempatan kepada masyarakat lapisan terbawah untuk meningkatkan pendapatan 'dan' selanjutnya bisa menabung dan melakukan pemupukan modal secara kolektil sebagai salah satu kegiatan sumber ekonomi dan kegiatan produktif.

Mengingat begitu besar potensi yang dimiliki zakat, maka diyakini sebagai panacea (obat mujarab) untuk memberantas kemiskinan. Namun sayangnya dalam operasionalisasinya, selama ini kita lihat zakat kebanyakan dilakukan sekadar untuk memenuhi rukun Islam (lebih banyak merupakan masalah pribadi) dan dampaknya tidak lebih sekedar meringankan béban konsumsi seseorang untuk beberapa hari. Padahal menurut banyak ilmuwan muslim menüliskan bahwa zakat dimaksudkan sebagai bagian dari sistem yang secara 
struktural diharapkan mampu mengatasi masalah kemiskinan dan mendorong perkembangan masyarakat. Inilah sebenarnya tantangan bagi umat Islam untuk memperbaiki kekurangan yang ada.

Kelahiran Undang-Undang tentang Pengelolaan Zakat beserta aturan pelaksanaannya, dalam perspektif ekonomi, dapat dilihat sebagai upaya serius pemerintah untuk mencoba memasukkan zakat sebagai bagian tak terpisahkan dariresources pembangunan dengan jalan méngatur lebih baik pengelolaannya. Hal ini berarti bahwa zakat sudah menjadi bagian dari sebuah sistem besar dari pembangunan. Dengan demikian, .sudah selayaknya pemerintah juga memikirkan lebih jauh tentang keberadaan zakat ini dalam sebuah model beserta dengan segala implikasi dan format interaksinya dengan resources lain dalam pembangunan, pajak misalnya.

Model makro ekonomi yang coba disampaikan di atas bisa menjadi alternatip entry point zakat ke dalam sebuah sistem ekonomi. Yang perlu diingat bahwa formulasi yang masih hipotetis tersebut masih merupakan pendekatan awal dan memerlukan serangkaian agenda penyesuaian model makro tersebut.

\section{Menyoal Peranan Negara dalam Zakat $^{3}$}

Dari tulisan para ahli fikih disebutkan, bahwa wajib para imam mengirim petugas untuk memungut zakat, karena nabi Muhammad SAW dan para khalifah sesudah beliáu menugaskan para pemungut zakat. Pelaksanaan zakat harus diawasi oleh penguasa, dilakukan oleh petugas dengan rapi dan teratur, dipungut dari orang yang wajib mengeluarkan untuk dibèrikan kepada orang yang berhak menerimanya. (Qardawi, 1991)
Di antara hadits-hadits nabi ialah hadits Abu Hurairah yang terdapat dalam hadits sahih. Bukhari-Muslim yang mengatakan bahwa Rasulullah SAW telah mengutus Umar lbu-Lutbiah sebagai petugas pemungut zakat. Sementara dalam beberapa hadits lainnya nabi pernah mengutus Ibnu. Sa'di; Abu Mas'ud, Abu Jahm bin Huzaifah, Amir, Qais bin Sa'ad, dan Wahid bin Uqbah sebagai petugas zakat. Keberadaan para petugas zakat ini sangat penting, karena di antara penduduk terdapat orang orang yang punya harta tapi tidak tahu akan kewajibannya. Ada juga di antara mereka yang mengetahui kewajiban tetapi ia kikir; oleh karena itu wajib adanya para pemungut zakat.

Dalam hadits sahih. Bukhari-Muslim dan yang lain-dari Ibnu Abbas, bahwa nabi SAW ketika mengutus Mu'az ke Yaman beliau berkata: "Beritahukan kepada mereka, bahwa Allah SWT.telah mewajibkan dari sebagian hartá mereka, untuk disedekahkan. Diambil dari orang kaya untuk diberikan kepada mereka yang fakir. Apabila mereka mentaatimu dalam hal ini, maka peliharalah akan kedermawanannya harta mereka, dan takutlah akan doa yang teraniaya. Sungguh tidak ada penghalang antara doá mereka itu dengan Allah SWT" (Hadits riwayat jamaah dari Ibnu Abbas)

Hadits ini menjelaskan, bahwa urusan zakat diambil oleh petugas untuk dibagikan, tidak dikerjakan sendiri oleh orang yang mengeluarkan zakat. Syekh Islam Hafiz Ibnu Hajar berkata: "Hadits ini dijadikan alasan, bahwa penguasa adalah orang yang bertugas untuk mengumpulkan dan membagikan zakat, baik ia sendiri secara

'Dalam pembahasan bagian ini penulis banyak mengikuti pendapat Yusuf Qardawi, 1991. 
langsung maupun wakilnya. Maka barangsiapa di antara mereka menolak mengeluarkan zakat, hendaknya zakat 'diambil dari orang itu dengan cara paksa".

Zakat bukarilah sebagai urusan pribadi, akan tetapi merupakan tugas pemerintah Islam. Islam mewakilkan penugasan menarik zakat, membagikannya pada mustahiknya. Hal itu dilakukan karena beberapa faktor, yaitu:

1. Sesunggutinya kebanyakan manusia telah mati hatinya atau terkena penyakit dan kelemahan. Untuk itu ada jaminan bagi si fakir dan haknya tidak diabaikan begitu saja.

2. Si fakir meminta kepada pemerintah, bukan dari pribadi orang kaya, untuk memelihara kehormatan dan air mukanya dari perasaan belas kasihan oleh sebab meminta, serta memelihara perasaan dan tidak melukai hatinya dari gunjingan dan kata-kata yang menyakitkan.

3. Dengan tidak memberikan urusan zakat ini pada pribadi-pribadi berarti menjadikan urusan pembagian zakat sama besarnya. Sebab terkadang banyak si kaya memberikan zakat pada seorang fakir saja, sementara fakir yang lain terlupakan. Tidak seorang pun yang mengerti keadaannyá, pádahal terkadang keadaannya lebih membu tuhkan.

4. Sesungguhnya zakat itu bukanlah hanya diberikan kepada pribadi si fakir, miskin dan ibnu sabil saja, akan tetapi ada di antara sasaran yang berhubungan dengán kèmaslahatan kaum muslimin bersama, yang tidak dapat dilakukan oleh perorangan, akan tetapi oleh penguasa dan lembaga musyawarah jamaah kaum muslimin, seperti memberi zakat pada golongan muallaf, mempersiapkan perlengkapan orang- orang untuk jihad fi sabilillah serta mempersiapkan para da'i untuk menyampaikan risalah Islam.

5. Sesungguhnya Islam agama dan pemerintahan, Qur'an dan kekuasaan. Untuk tegaknya pemerintahan dan kekuasaan ini dibutuhkan harta, yang dengan itu pula dilaksanakan syariatnya. Terhadap harta ini dibutuhkan adanya penghasilan. Dan zakat penghasilan yang penting dan tetap untuk kas negara dalam ajaran Islam. (Qardawi, 1991: 742-743).

Kewajiban zakat 'dalam pengelolaan zakat di atas juga diikuti dengan adanya hak negara untuk memberi sanksi duniawi bagi siapa saja para wajib zakat yang menging'kari kèwajiban ini, meskipun Allah SWT juga akan memberi sanksi baik di dunia maupun di akhirat. Hak negara ini antara lain terdapat dalam sebuah hadits yang diriwayatkan oleh Ahmad, 'Nasa'i, dan Abu Daud däri Bahaz bin Hakim: "Orang yang membayar zakat itu untuk memperoleh pahala maka ia pasti akan mendapat pahala itu, tetapi orang yang tidak membayarnya maka kita akan mengutip zakat itu besenta separuh kekayaan. Ini merupakan ketentuan tegas dari Tuhan, dan keluarga Muhammad tidak boleh mengambil zakat sedikit pun"

Dari hadits di atas terlihat bahwa demi menyelamatkan hak fakir miskin dan orangorang berhak lainnya maka negara diberi hak untuk memungutnya dengan cara apa pun - termasuk paksa - bahkan negara juga diberi hak untuk menyita harta dari orang yang bersangkutan separutinya.

Bahkan, lebih jauh mengenai pembang-kangan membayar zakat ini, Islam menginstruksikan agar pedang dicabut dan peperangan dinyatakan kepada orang-orang bersenjata yang membangkang membayar zakat. Islam tidak peduli apakah banyak 
jiwa harus melayang dan darah harus tertumpah untuk menjaga dan melindungi zakat tersebut. Hal ini telah dibuktikan oleh Khalifah Abu Bakr dan juga Usman ketika menghadapi para kaumnya yang mencoba membangkang membayar zakat dan mencoba memisahkan kewajiban zakat dan kewajiban sholat.

Sementara itu menurut Qardawi (1991: 80) hukuman bagi orang yang lalai dalam membayar zakat itu lebih banyak diserahkan kepada penilaian penguasa. Pemerintah bisa menerapkan hukuman itu bila berpendapat bahwa masyarakat sudah terlalu jauh membangkang tidak membayar zakat.

Kehadirañ Undang-Undang 'No 38 tahun 1999 tentang Pengelolaan' Zakat tampaknya ingin memerankan pemerintah dalam posisi yang lebih besar dan lebih kuat. $\mathrm{Hal}$ ini terlihat bahwia pembentúkan badan amil zakat. (baik di tingkat nasional maupun daerah) semuanya dibentuk oleh pemerintah (UU No 38/1999: pasal 6). Walaupun Keputusan Menteri Agama Nomor 581 tahun 1999 tentang Pelaksanaan UU nomor 38 tahun 1999 di mana dimungkinkan adanya lembaga amil zakat (institusi pengelolaan zakat yang sepenuhnya dibentuk atas prakarsa masyarakat dan oleh masyarakat yang bergerak di bidang da'wah, pendidikan, sosial dan kemaslahatan umat Islam), namun lembaga ini ini tetap harus mendapat pengukuhan oleh pemerintah. (Kep Menag 581/1999: pasal 21-24).

Posisi yang sedemikian kuat dari pemerintah ini diharapkan mampu mengoptimalkan pengelolaan zakat, baik dalam pengumpulan maupun pendistribusiannya. Hanya saja, posisi. yang kuat dari pemerintah ini tampaknya akan masih menghadapi beberapa kendala, di antaranya adalah ketentuan wajib bagi setiap WNI yang beragama Islam (UU 38/1999: pasal 2), belum diikuti oleh ketentuan sanksi bagi mereka yang tidak melaksanakannya. Padahal pada UU ini telah dengan tegas mengatur bahwa setiap kecurangan pengelola zakat akan dikenai sanksi baik perdata maupun pidana (pasal 21).

\section{Kelembagaan Zakat: Suatu Tinjauan}

Lembaga zakat yang dimaksud di sini adalah setiap institusi (baik individu maupun kolektif) yang melakukan aktivitas pengumpulan zakat dan kemudian membagikannya kepada yang berhak berdasarkan aturanaturan yang seharusnya. Hal ini didasarkan pada kenyataannyä di Indoniesia memang masih banyak sekali terdapat institusi yang berperan sebagai amil zakat.

Secara garis besar 'kelembagaan' zakat yang ada di Indonesia saat ini dengan sederhana dapat dibagi menjadi: (1) Individual, di mana para individu wajib zakat (muzakki) langsung membagikan zakat kepada para mustahiq (2) Ulama dan atau Pondok Pesantren (3) Takmir Masjid (4) Yayasan/LSM (5)Badan Amil Zakat, Infaq dan Shodaqoh (BAZIZ): berdasarkan Surat Keputusan Bersama Menteri Agama dan Menteri Dalam Negeri tăhun 1991.

Tanpa mengesampingkan arti penting dan sumbangan-sumbangan yang telah diberikan dari lembaga zakat 'di atas, perlu pula kita mencermati masih banyaknya kelemahan-kelemahain yang sifatnya manajerial dalam pengelolaannya, yaitu:

1. Belum tersusunnya peta kekuatan umat secara rinci, baik mengenai keberadaan muzakki maupun mustahiq. Keadaan ini dapat mengakibatkan luputnya perhatian kepada golongan mustahiq tertentu, padahal mungkin dia lebih berhak menerima bagian zakat

2. Kurang tercatatnya administrasi pengelolaan zakat secara sistematis, sehingga terkesan seadanya. 
3. Para amil terkadang bukan orang yang benar-benar paham akan zakat, baik dari aspek penarikan, pengelolaan maupun aspek distribusinya.

4. Masih lemahnya sistem pengelolaan zakat, baik meliputi manajemen pengumpulan (collecting), pendistribusian ataupun cara peningkatan produktivitas mustahiq (pemberdayaan mustahiq sehingga kelak dapat menjadi muzakki).

5. Belum terciptanya jaringan kerja (Net Work) antar lembaga zakat secara integratif yang mampu menggalang potensi umat yang tersebar di berbagai belahan nusantara serta belum mampunya menyentuh segala lapisan masyarakat yang memang selayaknya menerima bagian dari zakat.

6. Penyaluran zakat cenderung konsumtif dan kurang membangkitkan jiwa wirausaha yang mandiri.

Untuk dapat mewujudkan cita-cita zakat sebagai solusi masalah ekonomi dan kesejahteraan umat kini dan masa yang akan datang bukanlah hal yang mudah. Pengelolaan zakat yang profesional memerlukan tenaga yang terampil, menguasai masalah-masalah yang berhubungan dengan zakat, penuh dedikasi, jujur dan amanah. Di samping secara kontinyu harus terus dilakukan upaya-upaya penyempurnaan manajerial sesuai dengan perkembangan masyarakat. (lihat Mahfudh, 1994:145-153)

Kahadiran UU no 38 tahun 1999 yang telah dilengkapi pedoman pelaksanaannya melalui Keputusan Menteri Agama no 581 tahun 1999 diharapkan mampu menyelesaikan berbagai persoalan kelembagaan zakat yang selama ini ada. Akan tetapi, kehadiran aturan ini tampaknya masih akan meninggalkan beberapa agenda pelik dalam kelembagaan zakat, di antaranya:
1. Wajib zakat (Muzakki) yang dimaksud dalam UU NO 38/1999 tidaklah hanya orang-perorangan, tetapi juga badan yang dimiliki oleh orang muslim. Dengan adanya ketentuan ini berarti zakat menjadi bagian tak terpisahkan darifinancial report yang dibuat oleh suatu badan (usaha). Persoalannya adalah bagaimana zakat ini bisa diterima sebagai bagian dari kewajiban badan (usaha), bagaimana operasionalisasinya serta apa sanksi yang akan diberikan oleh pemerintah. bila suatu badan lalai dalam membayar kewajiban zakat ini.

2. Hubungan antartingkat (nasional, propinsi, kabupaten/kodya/kotip, kecamatan, desa) badan amil zakat/ lembaga amil zakat dengan prinsip koordinasi, integrasi, sinkronisasi dan konsultasi Kepmen 581/99: pasal 15) dalam pelaksanaannya masih akan dihadang berbagai persoalan baik itu berupa konkritisasi hubungan terlebih lagi operasional-teknis.

3. Hubungan antara badan amil zakat dan lembaga amil zakat bila ternyata kemudian tidak mampu diintegrasikan dalam suatu network, maka pada dasarnya tidak ada perubahan yang signifikan dari kelembagaan'zakat sebelumnya. Walaupun hal ini kemudian dieliminir dengan adanya ketentuan untuk pelaporan kegiatan kepada pemerintah dan DPR/DPRD.

4. Pelaporan kegiatan badan/lembaga amil zakat kepada DPR/DPRD akan dapat memunculkan persoalan baru. Karena DPR adalah lembaga representasi yang majemuk sifatnya -dan juga sebagai lembaga politik- sedangkan zakat merupakan kewajiban khusus bagi umat Islam, bukan tidak mungkin akan menimbulkan berbagai benturan kepentingan. 
Topik: Agenda Lanjutan Pasca lnstitusionalisasi Zakat, Arif Hartono

5. Dengan dimungkinkannya pemotongan pajak untuk membayar zakat (UU 38/ 99: pasal 14 ayat 3) memerlukan adanya mekanisme yang harus diatur lebih lanjut dan hal ini bukan persoalan sederhana. Di mana pajak dikelola oleh lembaga Dirjen Pajak sementara Badan Lembaga Amil Zakat di bawah pembinaan Depag.

6. Persoalan distribusi zakat juga masih menyisakan agenda-agenda persoalan yang sedemikian banyak; terutama masih beragamnya pandangan berkaitan dengan siapa yang seharusnya menerima zakat (lihat misalnya Mas'udi, 1991). Padahal dalam UU No 38 tahun 1999 ini permasalahan distribusi tidak terlalu banyak diatur dan dijelaskan.

\section{Bahan Bacaan}

Abod, Sheikh Ghazali (et al), 1992, islamic Finance, Kuala Lumpur, Quill Publisher.

Al-Qur'an dan Terjemahannya, Departemen Agama $\mathrm{PI}$

Ali, Muhammad Daud, 1988, Sistem Ekonomi Islam Zakat dan Wakaf, UI Press, Jakarta.

Ali, Mukti, 1981, Beberapa Persoalan Agama Dewasa Ini, Rajawali, Jakarta.

Ariff, Mohammad (editor), 1982, Monetary and Fiscal Economics of Islam, International Centre for Research in Islamic Economics, King Abdulaziz University, Jeddah-Saudi Arabia.

Departemen Agama Rl, Keputusan Menteri Agama Republik Indonesia Nomor 581 Tahun 1999 tentang Pelaksanaan Undang-Undang Nomor 38 Tahun 1999 tentang Pengelolaan Zakat.
Dumairy, 1994, Penyegaran Konsep-konsep Dasar Ekonomi, FE UII-ICMI-SBI, Yogyakarta, Materi Kursus Singkat dan Lokakarya Ekonomi Islam.

Glaid, Mahamoud A and Abdullah, Mohamed Aden, 1995, Reading in Public Finance in Islam, Islamic Research and Training Institute, and Islamic Development Bank, Jeddah.

Hartono, Arif, 1996, Optimalisasi Peran Zakat Sebagai Instrumen Pembangunan Ekonomi Umat, Jurnal Ekonomi, FE-UIi, Yogyakarta.

Kaht, Monzer, 1979, The Islamic Economy: Analytical of the Function of the Islamic Economic System, Palinfield, In., USA.

Kahf, Monzer, 1999, The Principles of Socio Economic Justice in the Contemporary Fiqh of Zakah, lqtisad: Journal of Islamic Economic, P3EIFE UII, Yogyakarta.

Mahfudh, MA. Sahal, 1994, Nuansa Fiqih sosial, LKIS, Yogyakart.

Mannan, Muhammad Abdul, 1993, Teoridan Praktek Ekonomi Islam, PT. Dana Bhakti Wakaf, Yogyakarta.

Mas'udi, Masdar Farid, 1991, Agama Keadilan: Risalah Zakat (Pajak) dalam Islam, Pustaka Firdaus, Jakarta.

Mas'udi, Masdar F., 1994, Kesetiakawanan Sosial: Pajak dan Zakat, FE UII-ICMI-SBI, Yogyakarta, Materi Kursus Singkat dan Lokakarya Ekonomi Islam.

Moehammad, Gunawan, 1982, Ajaran Ekonomi dari Al-Qur'an, Bagian Penerbitan Perpustakaan Pusat UII, Yogyakarta. 
Muhammad, Sahri, 1994, Ketentuan Syariah Tentang Zakat, FE UII-ICMI-SBI, Materi Kursiloka Ekonomi Islam.

Siddiqi, Muhammad Nejatultah, 1996, Role of State in the Economy, An Islamic Perspective, The Islamic Foundation, Leicester, United Kingdom.

Qardawi, Yusuf, 1991, Hukum Zakat, Litera Antar Nusa, Bogor.

Qardawi, Yusuf, 1995, Kiat Islam dalam Mengentaskan Kemiskinan, Gema Insani Press, Jakrta.

Qutthb, Sayid, 1984, Keadilan Sosial dalam Islam, Penerbit Pustaka, Bandung.
Rahardjo, M. Dawam, 1987, Perspektif Deklarasi Mekkah: Menuju Ekonomi Islami, Mizan, Bandung.

Saefudin, Ahmad Muflih, 1987, Ekonomi dan Masyarakat dalam Perspektif Islam, Rajawali Pers, Jakarta.

Sekretariat Kabinet Rl, Undang Undang No 38 Tahun 1999 lentang Pengelolaan Zakat, Lembaran Negara RI tahun 1999 Nomor 164.

Sulaiman, 1985, Thahir Abdul Muchsin, Menanggulangi Krisis Ekonomi Secara Islam, PT. Alma'arit, Bandung.

Yafie, Ali, 1994, Menggagas Fiqih Sosial, Mizan, Bandung. 